\title{
Latitudinal limits of coral reef growth
}

\author{
R. E. Johannes ${ }^{1}$, W. J. Wiebe ${ }^{1}$, C. J. Crossland ${ }^{1}$, D. W. Rimmer ${ }^{1}$ and S. V. Smith ${ }^{2}$ \\ ${ }^{1}$ CSIRO Marine Laboratories, P.O. Box 20, North Beach, Western Australia 6020 \\ ${ }^{2}$ Department of Zoology, University of Western Australia, Nedlands, Western Australia 6009
}

\begin{abstract}
In the Abrolhos Islands, site of a high-latitude coral reef, the net rate of community calcification is high but growth of frame-building corals is reduced. Our studies suggest that the latitudinal limits of coral reef development are often set by competition of macroalgae with corals, and that macroalgae are favoured at these latitudes by high nutrient concentrations, moderate water temperatures (for macroalgae) and possibly by reduced grazing pressure, while coral growth is reduced by temperatures which, for reef corals, are low
\end{abstract}

\section{INTRODUCTION}

For more than a century it has been assumed, but never proven, that minimum water temperatures set the latitudinal limits on coral reef development (Dana, 1843; Couthouy, 1844; Daly, 1915; Vaughan, 1919; Davis, 1928; Yonge, 1940; Hutchins, 1947; Fairbridge, 1950; Wells, 1957). Indeed 'no significant reefs occur where temperatures during the year fall below about $18^{\circ} \mathrm{C}$ except for very short periods' (Wells, 1957, p. 609). But do lower temperatures really inhibit coral reef development, or do other inhibiting factors simply come into operation at lower temperatures? Or, do low temperatures a $\mathrm{nd}$ other factors combine to limit reef development at high latitudes?

Here we show how studies of community structure and metabolism on reefs near their latitudinal limits help clarify this question. We report on measurements of primary productivity, calcification and dissolved nutrient concentrations in a reef community in the Abrolhos Islands, site of the southernmost welldeveloped coral reefs in the Indian Ocean.

This paper grew out of 2 multidisciplinary research expeditions to these islands. Some of the results referred to here have already been published by individual expedition members (Smith, 1981; Crossland, in press). But only after we consider these and other concurrent studies together, do the main points we wish to make below emerge.

\section{RESEARCH SITE}

The Abrolhos (sometimes called Houtman Abrolhos) Islands lie between $28^{\circ}$ and $29^{\circ}$ south latitude on the edge of the continental shelf, about $60 \mathrm{~km}$ off the coast of Western Australia. The reefs are complex, irregular and discontinuous but essentially annular and have been classified by Fairbridge (1948) as shelf atolls set on a relict karst topography and modified by a 'long and variegated' geological history. A warm current originating in the tropics flows southward along the continental shelf-break during autumn and winter in this area (Cresswell and Golding, 1980) moderating winter water temperatures. The annual temperature range is $18^{\circ}$ to $26^{\circ} \mathrm{C}$ (Fig. 1) with occasional brief excursions above and below these temperatures over shallow reef flats (Wilson and Marsh, 1980).

Luxuriant coral communities are present at some locations and coral diversity is exceptionally high for this latitude; 37 genera have been identified (Wilson and Marsh, 1980). Nevertheless, community structure differs substantially from that of typical low latitude reefs. Fleshy macroalgae abound in many areas. Thirty five percent of these algae belong to cool or cold temperate zone genera (Wilson and Marsh, 1980). Noteworthy among these is the kelp Ecklonia radiata which is abundant in some communities on the outer reef slopes and in channels where water turbulence is high. This species is the dominant macroalgae grow- 


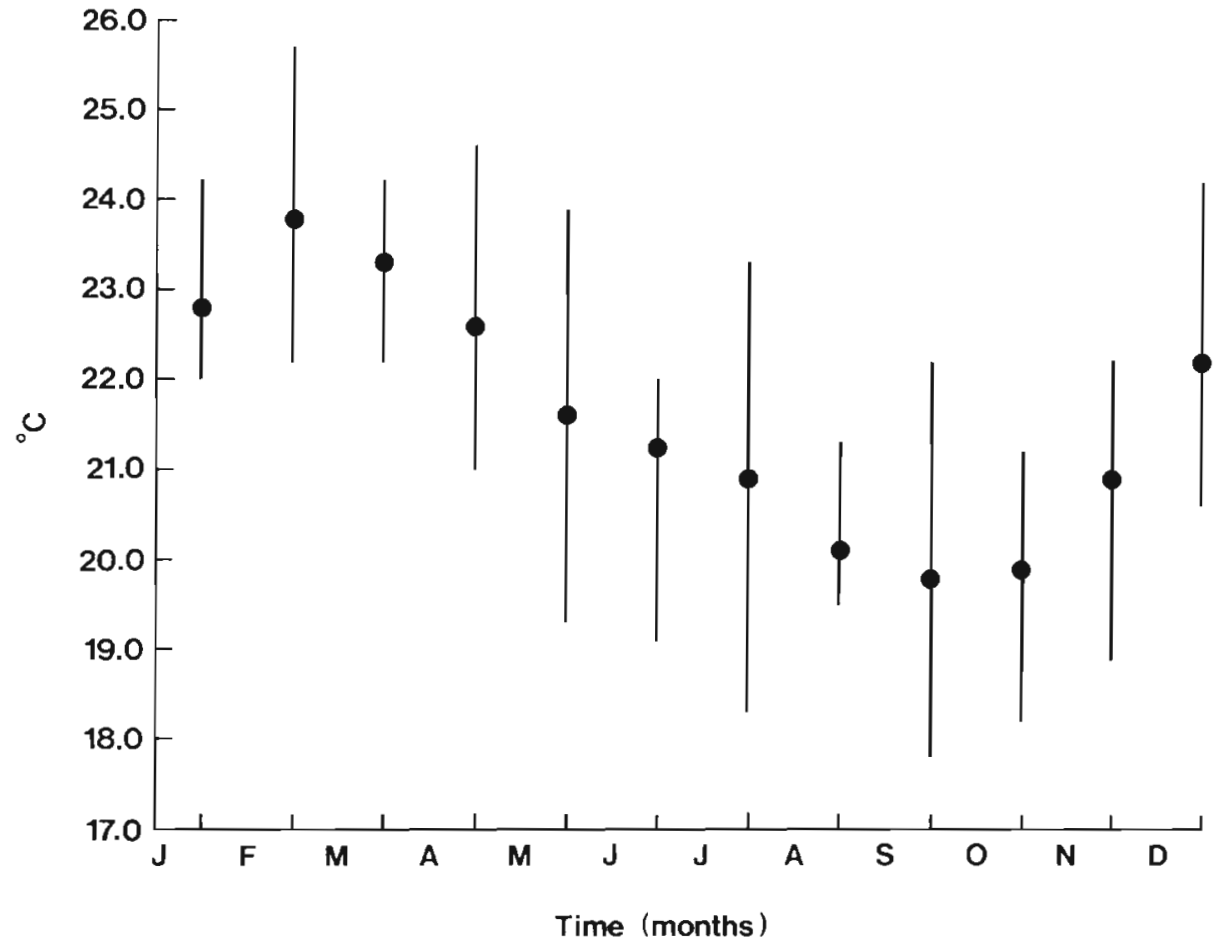

Fig. 1. Ten-yr means and ranges of monthly surface water temperatures, 1970-1980, Eastern Group. Abrolhos Islands ing below $1 \mathrm{~m}$ further south off the southwest coast of Western Australia (Kirkman, 1981). Only $25 \%$ of Abrolhos algae belong to tropical genera (Wilson and Marsh, 1980). Generally, peripheral reef flats are dominated by macroalgae, with coral coverage of less than $1 \%$ except in depressions and along lagoonward and seaward fringes (Wilson and Marsh, 1980).

Fish diversity is relatively low (285 species; G. R. Allen, pers. comm.). About $25 \%$ of these species are more typically found in temperate waters to the south. Zooplankton-eating fishes seem unusually sparse, and squirrelfish (Holocentridae), a ubiquitous element in low latitude coral reef communities, are entirely absent. Although surgeonfish (Acanthuridae) and large parrotfish (Scaridae) can be found on the reef flats, their biomass is much lower than is characteristic of low latitude reefs. It is doubtful that grazing by these species exerts the profound effects on reef flat comInunity structure in the Abrolhos that it typically does in lower latitudes (e.g. Hatcher, in press). Dominant herbivorous fish are two large temperate zone rudderfish Kyphosus cornelii and $K$. sydneyanus which browse without scraping the substrate.

Rock Iobsters Panulirus cygnus are noticeably more abundant than in typical low latitude reef communities and the reefs support a very substantial commercial lobster fishery; 1 to $3 \times 106 \mathrm{~kg}$ are taken annually from Abrolhos waters.

Our main study site was in the Easter Island group, on a lagoonal mound rising from a 3 to $5 \mathrm{~m}$ deep sand floor to a flat-topped coral community, the top of which is occasionally exposed on extreme low tides. Corals (primarily branching and tabular Acropora) covered about $75 \%$ of the reef area. Rock and sand patches, some with fairly abundant stands of the brown algae genera Turbinaria and Sargassum, were also present. Studies were carried out in September 1979 and March 1980 - times chosen to coincide with periods of minimum and Inaximum annual water temperatures.

\section{METHODS}

In order to measure reef community metabolism it was necessary to follow water masses as they moved across the study area at all hours of day and night. This was done by following a drogue consisting of a neutrally buoyant, water-filled plastic bottle as it crossed the reef. Water depth by the drogue was measured once per minute in order to determine mean water depth. Water samples were taken at the beginning and end of each transect. Many transects were run in duplicate by pairs of observers following drogues released several tens of meters apart.

Alkalinity and $\mathrm{pH}$ of the samples were determined within $2 \mathrm{~h}$ of sample collection in order to measure primary productivity and calcification of the reef community. Results were reported by Smith (1981). The remainder of each sample was filtered through a GFC glass fibre filter and frozen for later nutrient analysis. 
Standard methods for seawater analysis (Strickland and Parsons, 1972) were modified for use with small samples volumes $(5$ to $10 \mathrm{ml}$ ). Orthophosphate (DIP) was assayed with $10 \mathrm{ml}$ of water sample, silicate $(10 \mathrm{ml})$, nitrite $(5 \mathrm{ml})$ and nitrate $(12 \mathrm{ml})$, the last as nitrite after reduction in copperized-cadmím columns (10 cm $\times 4 \mathrm{~mm}$ diam.) (Wood et al, 1967). Dissolved organic phosphorus (DOP) was estimated according to Menzel and Corwin (1965), with $10 \mathrm{ml}$ seawater, and dissolved organic nitrogen (DON) with a $5 \mathrm{ml}$ sample (D'Elia et al., 1977). Optical density determinations were made with $5 \mathrm{~cm}$ light-path cuvettes.

\section{RESULTS AND DISCUSSION}

A comparison of mean dissolved nutrient concentrations in water impinging on our study site (Table 1) with concentrations from lower latitude reefs (Crossland, 1982) reveals the following: nitrate and DIP concentrations were significantly higher than those in most coral reef waters examined to date other than those that are polluted or subject to upwelling. Dissolved organic phosphorus and dissolved organic nitrogen concentrations were about as high as any reported from coral reef waters. Ammonia levels were highly variable both within and between sampling periods. Nitrite levels were typically low, constituting only a minor portion of total dissolved nitrogen. In summary, both total dissolved nitrogen and total dissolved phosphorus concentrations in our samples were unusually high for unpolluted reef waters.

Gross primary production at the study site was $12 \mathrm{~g}$ $\mathrm{C} \mathrm{m} \mathrm{m}^{-2} \mathrm{~d}^{-1}$ in September (low temperature period) and $21 \mathrm{~g} \mathrm{C} \mathrm{m}^{-2} \mathrm{~d}^{-1}$ in March (high temperature period) (Smith, 1981). These rates are higher than most published values for lower latitude reefs (Adey et al., 1977; Kinsey, 1979, in press).
Net community calcification rates were 13 and $50 \mathrm{~g}$ $\mathrm{CaCO}_{3} \mathrm{~m}^{-2} \mathrm{~d}^{-1}$ in September and March, respectively (Smith, 1981). These figures yield an estimated annual calcification rate of about $12 \mathrm{~kg} \mathrm{~m}^{-2}$. This is close to the upper limit of values reported for reefs at lower latitudes (Kinsey, 1979, in press). No correlation has been found between reef calcification rates and latitude in tropical waters (Kinsey, 1979). Our observations extend these findings to the latitudinal limit of coral reef growth. Why, then, does modern reef development not occur at higher latitudes?

The answer appears to relate to latitudinal changes in the outcome of competition between fleshy macroalgae and corals. When compared with shallow hardbottom temperate marine communities, typical low latitude coral reef communities are noteworthy for their low biomasses of fleshy macroalgae (e.g. Wanders, 1976b; Hatcher, in press). Although areas containing dense stands of fleshy macroalgae occur on some low latitude coral reefs in the absence of significant, documented upwelling or land-based sources of nutrient enrichment, such areas are circumscribed, constituting a minor fraction of total reef area (e.g. Wanders, 1976a; Connor and Adey, 1977; Adey et al., 1977). But high-latitude coral reef communities in a wide range of geographic locations contain high macroalgal biomasses occupying extensive areas and many different reef habitats (Table 2 ). Consistent with this is the observation that on transects carried out in representative bottom communities in the Abrolhos Islands, bottom coverage by fleshy macroalgae exceeded bottom coverage by corals in 18 out of 22 cases (Wilson and Marsh, 1980). It has been welldocumented that fleshy benthic algae can depress or prevent the growth of corals by overgrowth, shading, current-induced abrasion, competition for substratum, and by trapping sediments and rendering substrata unsuitable for coral settlement (for review see Johan-

Table 1. Dissolved nutrient concentrations $(\mu \mathrm{M})$ in water impinging upon Abrolhos study site, compared with nutrient concentrations in low-latitude coral reef waters not subject to anthropogenic nutrient enrichment or upwelling. In parentheses: standard errors

\begin{tabular}{|c|c|c|c|c|c|}
\hline Nutrient & \multicolumn{2}{|c|}{$\begin{array}{c}\text { September } \\
1979\end{array}$} & \multicolumn{2}{|c|}{$\begin{array}{c}\text { March } \\
1980\end{array}$} & \multirow{3}{*}{$\begin{array}{c}\begin{array}{c}\text { Range in } \\
\text { low-latitude } \\
\text { reef waters }\end{array} \\
0.1-0.3^{*}\end{array}$} \\
\hline $\mathrm{NO}_{3}$ & 1.17 & $(0.08)$ & 0.90 & $(0.04)$ & \\
\hline $\mathrm{NO}_{2}$ & 0.037 & $(0.003)$ & 0.058 & $(0.01)$ & \\
\hline $\mathrm{NH}_{3}^{2}$ & 0.296 & $(0.09)$ & 0.024 & $(0.005)$ & $0.2-0.5$ \\
\hline Dissolved organic $\mathrm{N}$ & 10.7 & $(0.54)$ & 8.7 & $(0.52)$ & $3.0-13.8$ \\
\hline Reactive phosphorus & 0.375 & $(0.075)$ & 0.21 & $(0.03)$ & $<0.30$ \\
\hline Dissolved organic $P$ & 0.35 & $(0.05)$ & 0.36 & $(0.04)$ & $<0.15$ \\
\hline $\mathrm{SiO}_{4}$ & 2.32 & $(0.10)$ & 2.21 & $(0.13)$ & $<2.0$ \\
\hline \multicolumn{6}{|c|}{ - Summarized from Crossland (1983) } \\
\hline
\end{tabular}


Table 2. High-latitude coral reef communities characterized by large standing crops of benthic macroalgae

\begin{tabular}{|lcl|}
\hline \multicolumn{1}{|c}{ Location } & $\begin{array}{c}\text { Approxi- } \\
\text { mate } \\
\text { latitude }\end{array}$ & \multicolumn{1}{c|}{ Reference } \\
\hline $\begin{array}{l}\text { Leh-Yiu, Taiwan } \\
\text { Sesoko Island. }\end{array}$ & $25^{\circ} \mathrm{N}$ & $\begin{array}{l}\text { Birkeland and Randall } \\
\text { (in press) }\end{array}$ \\
$\begin{array}{l}\text { Okinawa } \\
\text { Lord Howe Island, }\end{array}$ & $37^{\circ} \mathrm{N}$ & $\begin{array}{l}\text { C. J. Crossland, } \\
\text { own. obs. } \\
\text { South Pacific } \\
\text { Abaco, Bahamas and Done } \\
\text { Gulf of Aqaba, } \\
\text { Red Sea }\end{array}$ \\
$\begin{array}{l}\text { Houtman Abrolhos } \\
\text { Islands }\end{array}$ & $286^{\circ} \mathrm{N}$ & $\begin{array}{l}\text { Lighty (in press) } \\
\text { Mergner and } \\
\text { Schumacher (1974) } \\
\text { Wilson and Marsh } \\
\text { (1980) }\end{array}$ \\
\hline
\end{tabular}

nes, 1975). The growth of 10 colonies each of the corals Acropora cf. formosa and Pocillopora damicornis were monitored during 1979-80 near our study transect (Crossland, in press). All 20 colonies were free from encroaching algae at the beginning of the study in midwinter. During the following summer the growth of 4 of the $A$. formosa colonies was reduced by overgrowth and shading by fleshy algae, 2 colonies of $P$. damicornis were killed by macroalgai overgrowth and the growth of 2 others was reduced due to shading by macroalgae.

Although corals are not the only calcifiers in coral reef communities, they provide the essential primary framework within which other calcifying organisms and debris accumulate and cement to form the reef substructure (e.g. Stoddart, 1969). Reef community calcification rates can be high in the absence of corals (Kinsey, 1979). But without a coral framework many of the other calcifying organisms tend to be swept away by currents when they die, their fragments forming unconsolidated sediments rather than reefs. (The $\mathrm{CaCO}_{3}$ production rates measured by Smith [1981] are equivalent to reef accretion rates of about $8{\mathrm{~m} 1000 \mathrm{y}^{-1}}^{-1}$ if reef framework retained that material where it formed. But the physiography of Abrolhos reefs offers strong geological evidence that there has been little reef accretion over much of the reef surface since a previous low stand of the sea. The outlines of submerged features on the Abrolhos platforms, particularly the numerous 'blue holes', suggest that present carbonate accretion is no more than a thin veneer covering remnants of subaerial erosion shaped into karst topography during a previous low sea stand [Fairbridge, 1948, 1950.])

When macroalgae depress coral growth they depress a vital process in reef construction. The question follows: what favours the greater development of mac- roalgae in coral reef communities at higher latitudes? Several factors appear to be involved. Dissolved nutrient concentrations in surface waters generally increase with latitude (Sverdrup et al., 1942). An increase in dissolved nutrient concentrations associated with upwelling or sewage enrichment is well-known to stimulate the growth of macroalgae at the expense of corals (Banner and Bailey, 1970; Birkeland, 1977; Marszalek, in press; Walker and Ormond, 1982). Moreover, maximum growth rates of a variety of brown algae (Phaeophyceae), the dominant macroalgal cover in the Abrolhos (Wilson and Marsh, 1980) correlate well with periods of high concentrations of dissolved nutrients (Buggeln, 1974; Topinka and Robbin, 1976; Chapman and Craigie, 1977; Jackson, 1977; Prince and O'Neal, 1979; Wheeler and North, 1980). Similarly the kelp Ecklonia radiata, an important species in the Abrolhos, has been found to grow fastest during periods of high nutrient availability (Kirkman, pers. comm.).

In explaining the comparative dearth of corals in tropical upwelling regions, Birkeland (1977) pointed out that relatively low temperatures and nutrient richness are both characteristic of such waters, but that temperature is easier to measure. In consequence, the negative effect on corals of nutrient-stimulated macroalgal growth in such areas had been overlooked. As the present discussion indicates, this observation can also be applied to higher latitudes. (There is some evidence that a high DIP concentration [2 $\mu \mathrm{M}]$ may directly suppress calcification in coral reef communities [Kinsey and Davies, 1979]. This concentration is within the upper portion of the normal range of concentrations found in some temperate waters [Sverdrup et al, 1942], although about 6 times the concentrations found during the present study [Table 2]. Thus it seems unlikely that DIP levels in the Abrolhos are high enough to reduce calcification rates.)

Water temperatures characteristic of intermediate latitudes, while suboptimal for the growth of some reef corals (Buddemeier and Kinzie, 1976; see also below), appear especially favourable for the growth of a variety of marine algae. In the tropics some groups of algae grow fastest during the cooler months, while in temperate waters some groups grow fastest during the warmer months (Rao, 1970; Mathieson and Dawes, 1974; De Wreede, 1976; Josselyn, 1977; Ngan and Price, 1980; Thorhaug and Marcus, 1981). The moderate water temperatures found in regions where tropical and temperate algae overlap, such as the Abrolhos Islands, will thus be close to optimal for both such groups for longer periods of the year than at higher or lower latitudes.

Even in the absence of algal competition the growth rates of specimens of the corals Pocillopora damicornis 
and Acropora cf. formosa near our study site were somewhat lower than rates for the same species living in warmer waters (Crossland, 1983). Other community components, such as erect calcareous algae, foraminiferans, bryozoans, echinoderms and molluscs, thus accounted for the high community calcification rates we observed. This is not surprising; corals, although often visually dominant in reef communities, do not appear to account for the bulk of reef community calcification (Smith, 1973; Kinsey, 1979).

A comparative scarcity of grazing scarid and acanthurid fishes on Abrolhos reef flats reflects a general decrease in such fishes with latitude (Bakus, 1969; Birkeland and Randall, 1982). The reasons for this are unknown. Echinoid numbers are also generally very low on Abrolhos reefs (Wilson and Marsh, 1980), except in a few circumscribed areas. Grazing by such organisms often stimulates settlement and growth of corals by reducing the competitive impact of algae, but in other instances results in the physical destruction of corals as well as algae (e.g. Hatcher, in press; Lawrence and Sammarco, in press). This, plus an abundance of gastropod grazers (especially Turbo pulcher and Tectus pyтamis) and kyphosid browsers in the Abrolhos Islands prevents us from judging the significance of grazing as a factor influencing Abrolhos coral and macroalgal growth at present.

Not all high-latitude reefs conform to the conditions described above. Northwest Hawaiian Island reefs, for example, are not heavily populated with macroalgae, perhaps as a consequence of geographic isolation ( $R$. Grigg, pers. com.). Occasional extreme cold water events may set back coral growth in areas such as South Florida and the northern Bahama Banks (Roberts et al., 1982). [There is no evidence for such events occurring in the Abrolhos Islands (Fig. 1).] But because high-latitude reefs in a wide range of localities are characterized by large standing crops of macroalgae (Table 2), the effects of algae on coral growth reported here for the Abrolhos Islands may have considerable generality.

\section{CONCLUSIONS}

Progressing along any physical environmental gradient, physical conditions become less favourable for some species as they become more favourable for others. Along such a gradient the latter species will tend to replace the former as their competitive advantage increases. The distribution limits of species (and, by extension, communities) along such a gradient may thus be determined by competition rather than by direct abiotic limitations. Thus, at the latitudinal limits of coral reef development, the growth of macroalgal competitors with corals is favoured by high nutrient concentrations, moderate water temperatures and possibly by reduced grazing pressure, while coral growth is retarded by temperatures which, for reef corals, are low. Reef-building corals do grow at higher latitudes and lower temperatures, but not with sufficient vigour to create reefs. In Western Australia, for example, 6 species of reef corals are known from waters 5 degrees of latitude south of the Abrolhos Islands, around Esperance (Wilson and Marsh, 1980; Marsh, pers comm.) where the sustained minimum water temperature, about $16^{\circ} \mathrm{C}$, is 2 degrees below that for Abrolhos waters (CSIRO, unpubl.).

The direct effect of low water temperatures on coral growth is thus only one of several factors that combine to limit coral reef development latitudinally. Our observations support MacIntyre and Pilkey's (1969) caution concerning ecological or paleoecological generalizations based on single environmental parameters.

Finally, because nutrient-enrichment of reef waters favours the growth of macroalgae over corals, reef communities where macroalgal competition with corals is intense under normal conditions may be especially vulnerable to man-induced nutrient-enrichment, e.g. via sewage or agricultural runoff.

\section{LITERATURE CITED}

Adey, W. H., Adey, P. J., Burke, R., Kaufman, L. (1977). The Holocene reef systems of Eastern Martinique, French West Indies. Atoll Res. Bull, 218: 1-40

Bakus, G. J. (1969). Energetics and feeding in shallow marine waters. Int. Rev. gen exp. Zool. 4: 275-369

Banner, A. H., Bailey, J. H. (1970). The effects of urban pollution upon a coral reef system. Hawaii Inst. Mar. Biol. Tech. Rept. 25: 1-66

Birkeland, C. (1977). The importance of rate of biomass accumulation in early successional stages of benthic communities to the survival of coral recruits. Proc. Third Internat. Coral Reef Symp. Vol. I: 15-21

Birkeland, C., Randall, R. H. (in press). Facilitation of coral recruitment by echinoid excavations. Proc. Fourth Internat. Coral Reef Symp., Univ. Philippines, Manila

Buddemeier, R. W., Kinzie, R. A. III. (1976). Coral growth. Oceanogr. mar. Biol. A. Rev. 14: 183-225

Buggeln, R. G. (1974). Physiological investigations on Alaria esculenta (L.) Grev. (Laminariales). I. Elongation of the blade. J. Phycol. 10; 283-288

Chapman, A. R. O., Craigie, J. S. (1977). Seasonal growth in Laminaria longicrurus: relations with dissolved inorganic nutrients and internal reserves of nitrogen. Mar. Biol. 40: $197-205$

Connor, J., Adey, W. (1977). The benthic algal composition standing crop and productivity of a Caribbean algal ridge Atoll Res. Bull. 211: 1-15

Couthouy, J. P. (1844). Remarks upon coral formations in the Pacific; with suggestions as to the causes of their absence in the same parallels of latitude on the coast of South America. Boston J. Nat. Hist. 4: 66-105

Cresswell, G. R., Golding, T J. (1980). Observations of a 
south-flowing current in the Southeastern Indian Ocean. Deep Sea Res. 27: 449-466

Crossland, C. J. (in press). Seasonal growth of Acropora cf formosa and Pocillopora damicornis on a high latitude reef (Houtman Abrolhos, Western Australia). Proc. Fourth Internat. Coral Reef. Symp., Univ. Philippines, Manila

Crossland, C. J. (1983). Dissolved nutrients in coral reef waters. In: Barnes, D. J. (ed.) Growth, maintenance and change of coral reefs. Australian Nat. Univ. Press, Canberra

Daly, R. A. (1915). The glacial control theory of coral reefs. Proc. Am. Acad. Arts Sci. 51: 155-251

Dana, J. D. (1843). On the temperature limiting the distribution of corals. Am. J. Sci. 45: 130-131

Davis, W. M. (1928). The coral reef problem. Spec. Publs Am. geogr. Soc. 9: 1-596

D'Elia, C. F., Steudler, P. A., Corwin, N. (1977). Determination of total nitrogen in aqueous samples using persulphate digestion. Limnol. Oceanogr. 22: 760-764

De Wreede, R. E. (1976). The phenology of three species of Sargassum (Sargassaceae, Phaeophyta) in Hawaii. Phycologia 15: 175-183

Fairbridge, R. W. (1948). Notes on the geomorphology of the Pelsart Group of the Houtman's Abrolhos Islands. J. R Soc. West. Aust. 33: 1-43

Fairbridge, R. W. (1950). Recent and Pleistocene coral reefs of Australia. J. Geol. 58: 330-401

Hatcher, B. G. (in press). Grazing in coral reef ecosystems. In: Barnes, D. J. (ed.) Growth, maintenance and change of coral reefs. Australian Nat. Univ. Press, Canberra

Hutchins, L. W. (1947). The bases for temperature zonation in geographical distribution. Ecol. Monogr. 17: 325-335

Jackson, G. A. (1977). Nutrients and production of giant kelp, Macrocystis pyrifera, off southern California. Limnol. Oceanogr. 22: 976-996

Johannes, R. E. (1975). Pollution and degradation of coral reef communities. In: Wood, E. J. F., Johannes, R. E. (eds.) Tropical marine pollution. Elsevier, Amsterdam, p. 13-51

Josselyn, M. N. (1977). Seasonal changes in the distribution and growth of Laurencia poitei (Phaeophyceae, Ceramiales) in a subtropical lagoon. Aquat. bot. 3: 217-229

Kinsey, D. W. (1979). Carbon turnover and accumulation by coral reefs. Ph.D. thesis. Univ. Hawaii, Dissertation Abstracts order No. 8012258

Kinsey, D. W. (in press). Standards of performance in coral reef primary production and carbon turnover. In: Barnes, D. J. (ed.) Growth, maintenance and change of coral reefs. Australian Nat. Univ. Press, Canberra

Kinsey, D. W., Davies, P. J. (1979). Effects of elevated nitrogen and phosphorus on coral reef growth. Limnol. Oceanogr. 24: $935-940$

Kirkman, H. (1981). The first year in the life history and the survival of the juvenile marine macrophyte, Ecklonia radiata (Turn.) J. Agardh. J. exp. mar. Biol. Ecol. 55: $243-254$

Lawrence, J. M., Sammarco, P. W. (in press). Effect of feeding on the environment. Echinoidea. In: Jangoux, M., Lawrence, J. M. (eds.) Echinoderm nutrition. A. A. Balkema Press, Rotterdam

Lighty, R. G. (in press). Fleshy-algal domination of a modem Bahamian Barrier reef: example of an alternate climax reef community. Proc. Fourth Internat. Coral Reef Symp., Univ. Philippines, Manila

MacIntyre, I. G., Pilkey, O. H. (1969). Tropical reef corals: tolerance of low temperatures on the North Carolina Continental Shelf. Science, N.Y. 166: 374-375

Marszalek, D. S. (in press). Effects of sewage effluents on reef corals. Proc. Fourth Internat. Coral Reef Symp., Univ. Philippines, Manila

Mathieson, A. C., Dawes, C. J. (1974). Ecological studies of Floridean Eucheuma (Rhodophyceae, Ceramiales). II. Photosynthesis and respiration. Bull. mar. Sci. 24: 274-285

Menzel, D. W., Corwin, N. (1965). The measurement of total phosphorus in seawater based on the liberation of organically bound fractions by persulphate oxidation. Limnol. Oceanogr. 10: 280-282

Mergner, H., Schuhmacher, H. (1974). Morphology, ecology and zonation of coral reefs at Aqaba, Gulf of Aqaba, Red Sea. Helgoländer wiss. Meeresunters. $26: 238-258$

Ngan, Y., Price, I. R. (1980). Seasonal growth and reproduction of intertidal algae in the Townsville region (Queensland, Australia). Aquat. bot. 9: 117-134

Prince, J. S., O'Neal, S. W. (1979). The ecology of Sargassum pteropleuron Grunow (Phaeophyceae, Fucales) in waters off South Florida. I. Growth, reproduction and population structure. Phycologia 18: 109-114

Rao, K. R. (1970). Studies on the growth and phycocolloid content in Hypnea musciformis (Wulf.) Lamour. Botanica mar. 13: 163-165

Roberts, H. H., Rouse, L. J., Jr., Walker, N. D., Hudson, J. H. (1982). Cold-water stress in Florida Bay and Northern Bahamas: a product of winter cold-air outbreaks. J. sedim Petrol. 52: 145-155

Smith, S. V. (1973). Carbon dioxide dynamics: a record of organic carbon production, respiration, and calcification in the Eniwetok windward reef flat community. Limnol. Oceanogr. 18: 106-120

Smith, S. V. (1981). The Houtman Abrolhos Islands: carbon metabolism of coral reefs at high latitude. Limnol. Oceanogr. 26: 612-621

Stoddart, D. R. (1969). Ecology and morphology of recent coral reefs. Biol. Rev. 44: 433--498

Strickland, J. D. H., Parsons, T R. (1972). A practical handbook of seawater analysis, 2nd ed. Bull. Fish. Res. Bd Can. 167

Sverdrup, H. U., Johnson, M. W., Fleming, R. H. (1942). The oceans. Prentice-Hall, New Jersey

Thorhaug, A., Marcus, J. H. (1981). Effects of temperature and light on attached forms of tropical and semi-tropical macro-algae potentially associated with ocean thermal energy conversion machine operation. Botanica mar. 24 393-398

Topinka, J. A., Robbins, J. V. (1976). Effects of nitrate and ammonia enrichment on growth and nitrogen physiology in Fucus. Limnol. Oceanogr. 21; 659-664

Vaughan, T W. (1919). Corals and the formation of coral reefs. Ann. Rept. Smithsonian Instn. 17: 189-238

Veron, J. E. N., Done, T. J. (1979). Corals and coral communities of Lord Howe Island. Aust. J. mar. Freshwat. Res. 30: 203-236

Wanders, J. B. W. (1976a). The role of benthic algae in the shallow reef of Curaçao (Netherlands Antilles) II. Primary productivity of the Sargassum beds on the north-east coast submarine plateau. Aquat. Bot. 2: 327-335

Wanders, J. B. W (1976 b). The role of benthic algae in the shallow reef of Curaçao (Netherlands Antilles) I. Primary productivity in the coral reef. Aquat. Bot. 2: 235-270

Walker, D. I., Omnond, R. F. G. (1982). Coral death from sewage and phosphate pollution at Aqaba. Red Sea. Mar Pollut. Bull. 13: 21-25

Wells, J. W (1957). Corals. Mem. geol. Soc. Am. 67 (1): $1087-1104$

Wheeler, P. A., North, W. J. (1980). Effects of nitrogen supply on nitrogen content and growth rate of juvenile Macrocys- 
tis pyrifera (Phaeophyta) sporophytes. J. Phycol. 16: $577-582$

Wilson, B. R., Marsh, L. M. (1980). Coral reef communities at the Houtman Abrolhos, Western Australia, in a zone of biogeographic overlap. Proc. Internat. Symp. Mar Biogeogr Southern Hemisphere, p. 259-278
Wood, E. D., Armstrong, F. A. J., Richards, P. A. (1967) Determination of nitrate in seawater by cadmium-copper reduction to nitrite. J. mar. biol. Ass. U.K. 47: 23-31

Yonge, C. M. (1940). The biology of reef-building corals. Scient. Rep. Gt Barrier Reef Exped. 1: 353-391

This paper was submitted to the editor; it was accepted for printing on December 9, 1982 